İş ve İnsan Dergisi | The Journal of Human and Work

Y1l | Year: Nisan | April 2020

Cilt-Say1 | Volume-Issue: 7 (1)

ss I pp: $33-47$

doi: 10.18394/iid.593944

e-ISSN 2148-967X

https://dergipark.org.tr/tr/pub/iid

Araştırma Makalesi

\title{
Algılanan Gelecekteki İstihdam Edilebilirlik Ölçeğinin Türkçeye Uyarlanması
}

\author{
Turkish Adaptation of Perceived Future Employability Scale
}

\begin{tabular}{l} 
\\
\hline MAKALE BİLGİSİ \\
\hline Anahtar Kelimeler: \\
Algllanan Gelecek, İstihdam \\
Edilebilirlik, Geçerlik, \\
Güvenirlik, Uyarlama \\
\hline Tarihler : \\
Geliş 18 Temmuz 2019 \\
Düzeltme geliş 24 Eylül \\
2019 \\
Kabul 02 Ekim 2019
\end{tabular}

\section{A R T I C LE INFO}

\section{Keywords:}

Perceived Future,

Employability, Validity, Reliability, Adaptation

Article history:

Received 05 July 2019

Received in revised form 15

September 2019

Accepted 02 October 2019

\section{Serdar Alkın ${ }^{\text {a }}$, Ozan Korkmaz ${ }^{\text {b }}$, Seher Balcı Çelik ${ }^{\mathrm{c}}$}

\begin{abstract}
ÖZ
Bu çalışmanın amacı Algllanan Gelecekteki İstihdam Edilebilirlik Ölçeği'nin (AGIEË) Türkçeye uyarlanarak üniversite ögrencileri için geçerlik ve güvenirliğinin incelenmesidir. Araștırmanın çalışma grubunu Karadeniz Bölgesi’nde bulunan iki üniversitede öğrenim gören 461 öğrenci oluşturmaktadır. AGIEÖ'nün geçerlik çalışması kapsamında doğrulayıcı faktör analizi yapılmış, yakınsak ve ayırt edici geçerlik ve eş değer ölçek geçerliği incelenmiştir. Doğrulayıcı faktör analizi sonucunda orijinal yapıdaki gibi altı faktörlü yapının uyum indekslerinin kabul edilebilir değerlerde olduğu belirlenmistitir. Benzer şekilde, yapılan hesaplamalar sonucunda ölçeğin yakınsak ve ayırt edici geçerliği sağladığı görülmektedir. Eş değer ölçek geçerliği sonucunda da AGIEÖ'nün alt boyutları ile Kariyer Uyum Yetenekleri Ölçeği'nin alt boyut ve toplam puanları arasında pozitif yönde istatistiksel olarak anlaml ilişkiler bulunmuștur. Diğer yandan AGIEÖ'nün eğitim kurumunun beklenen itibarı alt boyutu ile Kariyer Stresi Ölçeğinin toplam ve olumsuz duygular alt boyutu arasında negatif, düşük düzeyde anlaml ilişkiler bulunmuştur. Ölçeğin toplam ve alt boyutlarına ilişkin Bileşik Güvenirlik ve Cronbach Alfa iç tutarlllık katsayılarının yeterli düzeyde olduğu bulunmuştur. Algllanan Gelecekteki İstihdam Edilebilirlik Ölçeği'nin üniversite öğrencilerinin gelecekteki becerilerini, deneyimlerini, iletişim ağlarını, kişisel özelliklerini iş gücü piyasası hakkindaki bilgilerini ve eğitimini tamamlayacakları üniversitenin itibarı hakkındaki algılarını ölçmede yeterli geçerlik ve güvenirlik değerlerine sahip olduğu söylenebilir.
\end{abstract}

\begin{abstract}
A B S T R ACT
The aim of this study was to adapt the Perceived Future Employment Scale (PFES) into Turkish language and examine the reliability and validity among university students. The participants consisted of 461 students studying at two different universities in the Black Sea Region. In the validity study, confirmatory factor analysis was conducted and the validity of the equivalent scale was examined. As a result of the confirmatory factor analysis, the fit indexes of the sixfactor structure as in the original structure were found to be acceptable. Similarly, the results of the calculations show that the scale provides convergent and discriminant validity. As a result of the validity of the equivalent scale, a statistically significant relationship was found between the subscales of the PFES and the subscales and total scores of the Career Adaptation Capabilities Scale. On the other hand, negative and low level of significant relationships were found between the expected reputation sub-dimension of the PFES and the total and negative emotions subdimension of the Career Stress Scale. Composite reliability and Cronbach's alpha internal consistency coefficients for the scale were found to be sufficient. As a result, it can be said that the Perceived Future Employability Scale has sufficient validity and reliability values for measuring university students' future skills, experiences, communication networks, personal characteristics, knowledge about the labor market and their perceptions about the reputation of the university they will complete their education.
\end{abstract}

\footnotetext{
a İletişim kurulacak yazar, Uzm. Psk. Dan., Tokat Milli Eğitim Müdürlüğ̈̈, Tokat, Türkiye. E-mail: pd.serdaralkin@gmail.com. ORCID: 0000-0001-8934-3007

b Öğr. Gör.., Karamanoğlu Mehmetbey Üniversitesi, Psikolojik Danışma ve Rehberlik Uygulama ve Araştırma Merkezi, Karaman, Türkiye.E-mail: pd.ozankorkmaz@gmail.com.ORCID: 0000-0002-0541-200X

c Prof. Dr., Ondokuz Mayıs Üniversitesi, Eğitim Fakültesi, Eğitim Bilimleri, Rehberlik ve Psikolojik Danışmanlık Bölümü, Samsun, Türkiye.E-mail: sbalci@omu.edu.tr. ORCID: 0000-0001-9506-6528
} 


\section{GİRIŞ}

Örgütlerin faaliyet gösterdiği ekonomik ve sosyal bağlamlar, küreselleşmenin etkisi ve teknolojideki hızlı gelişmeler nedeniyle uyum taleplerini arttırmış ve işgücü piyasası son yıllarda büyük ölçüde değişmiştir. Bu sayede iş yerleri daha esnek hale gelmiştir (Castells, 2000; Hiltrop, 1995; Kalleberg, 2001). Örgütün çevresini olduğu gibi üyeleri ile arasındaki ilişkiyi de etkileyen bu esnekliğin çalışanlar için de etkileri olmuştur. Buna göre iç ve dış piyasa işgücünde rekabet etmek isteyen çalışanlar daha esnek olmalıdır (Hesselink \& Van Vuuren, 1999; Hirsch, 1991). Bireyin daha esnek ve öngörülemeyen istihdam ilişkileri ile başa çıkabilmesini sağlayan şeylerden bir tanesi istihdam edilebilirliktir.

İstihdam edilebilir olmak, bireyin çalkantılı bir örgütsel ortamla uğraşmaya hazır olmasını sağlayan yollardan birisidir (Bernston, Sverke \& Marklund, 2006). İstihdam edilebilirlik; onu belirleyen koşullar ve bireysel kariyerleri şekillendirmedeki rolü ile sürekli ve değerli bir iş arayanlar için kilit bir amaç olarak ortaya çıkmıştır (Forrier \& Sels, 2003). Genel bir tanımla istihdam edilebilirlik; bireyin istihdamı kazanma ve sürdürme kapasitesini ifade etmektedir (Hillage \& Pollard, 1998; Sanders \& Grip, 2004). İstihdam edilebilirlik, bir bireyin iş ve kariyer konusundaki yaklaşımının sonucudur. İstihdam edilebilir kişi, değişimi öngörmek ve bu değişime proaktif bir şekilde yanıt vermek amacıyla, istek ve kapasiteye sahip ayrıca esnek ve uyarlanabilir olmalıdır (Clarke, 2008).

Yirminci yüzyılın başlarında ilk kez kullanılan istihdam edilebilirlik kavramı çalışmaya istekli ve çalışmaya ihtiyacı olan, yani "istihdam edilebilir" bireyleri, "işsiz" olan bireylerden ayıran bir kavram olarak ortaya çıkmıştır (Gazier, 1998). 1950 ve 1960'll yıllarda iş ve benlikle ilgili bir tutuma daha fazla atıfta bulunurken, 1970 'lerde iş için gerekli olan bilgi ve becerileri ifade etmek amaciyla kullanılmıştır. 1980'li yıllarda işgücü piyasası esnekliği için gerekli olan devredilebilir becerilerle ilgiliyken, 1990'lardan bu yana ise bireylerin, özellikle iş değiştirmek zorunda olmaları durumunda iş hazırlığına nasıl devam edebileceklerini ifade etmektedir (Guilbert, Bernaud, Gouvernet \& Rossier, 2016). İstihdam edilebilirlik, sadece işsiz olan bireyler için değil, çalışan bireylerin tamamı için de önemli bir kavram haline gelmiştir. İstihdam edilebilirliğin, değişen koşullara bağlı olarak ortaya çıkan iş güvencesizliğine bir alternatif oluşturacağ düşünülmüştür. Kavram; hükümetlerden, araştırmacılardan ve profesyonellerden büyük ilgi görmüş, ekonomi, eğitim ve psikoloji gibi çeşitli disiplinlerde çalışılmıştır (Rothwell, Jewell \& Hardie, 2009; Vanhercke, De Cuyper, Peeters \& De Witte, 2014).

Algilanan istihdam edilebilirlik Hillage ve Pollard (1998) tarafından bireyin işgücü piyasasında sürdürülebilir istihdam yoluyla kendi kendine yeterli gelecek şekilde hareket ederek potansiyelini gerçekleştirme kapasitesi şeklinde tanımlanırken, Berntson ve Marklund, (2007) ile Vanhercke ve diğerlerine (2014) göre bireyin varlığını sürdürmek veya yeni istihdam bulmak amaciyla kendi imkânlarını algılaması şeklinde tanımlanmıştır. Başka bir tanımda ise Cuyper, Claudia, Bernston, Eric ve Alarco (2008) tarafindan bireylerin iç ve diş işgücü piyasasında bulunan mevcut seçenekleri algılaması olarak belirtilmiştir. Algılanan istihdam edilebilirlik, iş güvencesinin düşük olduğu dönemde çalışanlar için yaklaşmakta olan kritik kaynak olarak gösterilmektedir (Silla, De Cuyper, Gracia, Peiro \& De Witte, 2009).

Algılanan istihdam edilebilirlik; algılanan beceriler, deneyim, iletişim ağı, kişisel özellikler ve işgücü piyasası bilgisi gibi çeşitli boyutları içermektedir (Berntson \& Marklund, 2007). Algilanan beceriler; iş becerileri ve genel becerilerle ilgili bilgileri, akademik başarıları (Pool, Qualter \& Sewell, 2014; Rothwell, Herbert \& Rothwell, 2008), iş arama becerilerini (Harvey, 2001; Hillage \& Pollard, 1998), ustalıklı uygulamaları (Knight \& Yorke, 2004), istihdam edilebilirlik ve bunu sürdürme ile ilgili tüm yetkinlikleri içermektedir. Algılanan deneyim; iş, çalışma ve yaşam deneyimlerini içermektedir (Pool vd., 2014; Rothwell \& Arnold, 2007). İletişim ağı oluşturma; bireyin işle ilgili ve sosyal bağlantılarının (Rothwell \& Arnold, 2007; Van der Heijde \& Van der Heijden, 2005) kapsamı ve kullanışlılığı anlamını taşımaktadır. Kişisel özellikler; bireyin kendini tanıma, becerilerini öğrenme ve geliştirmesiyle ilgili durumları kapsamaktadır (Rothwell \& Arnold, 2007). Ayrica öz yeterlik, beklenti, üst bilişsel yeterlikler (Knight \& Yorke, 2004; Van der Heijde \& Van der Heijden, 2005), problem çözme becerileri, duygusal zeka ve özyönetim gibi esneklik ve uyarlanabilirliği sağlayan aracı özellikler içerir (Pool vd., 2014). İşgücü piyasası bilgisi ise; işgücü piyasasındaki firsatların farkındalığını (Rothwell \& Arnold, 2007; Rothwell vd., 2008), iş anlayışı ve organizasyonu (Harvey, 2001; Knight \& Yorke, 2004; Van der Heijde \& Van der Heijden, 2005), kariyer gelişimi ve öz yönetimi anlama (Pool vd., 2014) ile mesleki başarıyı sağlamaya yönelik stratejik bir yaklaşımı benimseme konusundaki farkındalığı içermektedir (Hillage \& Pollard, 1998).

Genç yetişkinler için algılanan gelecekteki istihdam edilebilirlik, bu kişilerin eğitimlerini tamamladıktan sonraki mesleki benliklerinin temsilidir. Bireylerin 
mesleki benliklerini de içeren gelecek benlikleri, kişinin ne olabileceğine dair kendine özgü, kişiselleştirilmiş temsiline atıfta bulunur (Cross \& Markus, 1991; Ellen, Wiener \& Fitzgerald, 2012; Markus \& Nurius, 1986). Genç yetişkinlerin algılanan gelecekteki istihdam edilebilirliği mevcut mesleki düşüncelerini, bunun etkilerini ve davranışlarını yönlendirmektedir. Bireyin örgün eğitimini tamamladıktan sonra istihdam edilebilirlik düzeyine dair görüşlerinin; mevcut becerileri, deneyimleri, iletişim ağları, kişisel özellikleri ve mevcut algilanabilir istihdam edilebilirlik durumunun değerlendirilmesiyle ilgili olması beklenir. Algilanan gelecekteki istihdam edilebilirlik durumları ile hayal edilen bu hedefe yönelik mevcut ilerlemeleri arasındaki bir tutarsızlık olduğunda (örneğin, hedefin karşılanamayacağının değerlendirilmesi) birey tutarsızlığı azaltacak davranışlarda bulunacak ya da algılarını bilişsel olarak ayarlayacak (örneğin, gelecekle ilgili beklentilerini azaltacak) veya hem davranışlarını hem de beklentilerini değiştirecektir. Bireyin, algilanan gelecekteki istihdam edilebilirliğine ulaşmaya ne kadar yaklaştı̆̆ davranışların ve uygulanan stratejilerin etkinliğine yani ne kadar iyi öz düzenleme yaptıklarına dayanır (Lord, Diefendorff, Schmidt \& Hall, 2010).

Türkiye'de üniversite mezunu olup iş bulamayan veya eğitim aldığı alandaki işten başka bir işe girmek zorunda kalan çok sayıda kişi bulunmaktadır. Türkiye İstatistik Kurumu'nun (TÜİK) 2019 yılı Haziran ayında açıkladığı verilere göre, Mart 2019 itibariyle Türkiye'de işsizlik oranı $\% 14.1$ olurken, genç nüfusta bu oran $\% 25.2$ olarak gerçekleşmiştir. Yaklaşık dört mezundan birisinin iş bulamadığı ülkemizde, üniversite eğitimine devam eden bireylerin algilanan gelecekteki istihdam edilebilirlik durumlarına ilişkin bulguların ortaya koyulması bireylerin kariyerlerini yapılandırma açısından önemli görülmektedir. Alanyazın taramasında Gerçek ve Atay’ın (2017) örneklem grubu beyaz yakalı çalışanlardan oluşan, Rothwell ve Arnold (2007) tarafindan geliştirilen Algılanan İstihdam Edilebilirlik Ölçeği'ni Türkçe'ye uyarladığ1 görülmüştür. Ancak Türkiye'de büyük çoğunluğu üniversite eğitimi almakta olan ve mezun olduktan sonra yaklaşık dörtte birinin işsiz kalma ihtimalinin olduğu genç yetişkinlerin istihdam edilebilirlik algısını ölçmek amacıyla geliştirilen veya uyarlanan bir ölçeğin olmadığ görülmüştür. Dolayısıyla bu araştırmada Gunawan, Creed ve Glendon (2019) tarafindan genç yetişkinler için geliştirilen Algılanan Gelecekteki İstihdam Edilebilirlik Ölçeğinin Türk Kültürüne uyarlanması amaçlanmıştır.

\section{YÖNTEM}

\section{1. Çalışma Grubu}

Çalışma Karadeniz Bölgesinde yer alan iki farklı ildeki devlet üniversitelerinde öğrenim gören öğrenciler üzerinde gerçekleştirilmiştir. Araştırmanın çalışma grubunu 180 (\%39) erkek ve 281 (\%61) kadın olmak üzere toplam 461 öğrenci oluşturmaktadır. Öğrencilerin 124'ü (\%26.8) 1'inci sinıf, 165'i (\%35.7) 2'inci sinıf, 76's1 (\%16.6) 3'üncü sinıf ve 96's1 (\%20.9) 4'üncü sinıfta öğrenim görmektedir. Öğrencilerin yaş ortalamas1 20.65 ( $\mathrm{SS}=3.12$ ) olup, yaşları 18 ile 40 arasında değişmektedir. Araştırmaya katılan öğrencilerin \%8.3'ü $(\mathrm{n}=38)$ kendini sosyoekonomik yönden düşük düzeyde alg1larken, \%87.8'i $(\mathrm{n}=405)$ orta düzeyde, \%3.9'u $(\mathrm{n}=18)$ ise yüksek düzeyde algıladığını belirtmiştir. Ölçeğin faktör yapısını incelemek için 235 öğrenci [133 kadın (\%56.6), 102 erkek (\%43.4)], uyum geçerliğini incelemek için 146 öğrenci [86 kadın (\%58.9), 60 erkek (\%41.1)], test-tekrar test güvenirlik analizini incelemek için 60 ögrrenci [51 kadın (\%85), 9 erkek (\%15)], dilsel eşdeğerliğini incelemek için 20 öğrenci [11 kadın $(\% 55), 9$ erkek (\%45)] çalışmaya dahil edilmiştir. İlk aşamada ölçeğin faktör yapısını incelemek amacıyla 235 öğrenciye ulaşılmıştır. Faktör yapısı incelendikten sonra farklı gruplardaki katılımcılardan geçerlik ve güvenirlik için ayrı veri toplanmıştır. Öğrencilerin 183'ü (\%39.6) eğitim fakültesi, 251'i (\%54.4) mühendislik fakültesi ve 27'si (\%6) diğer fakültelerde öğrenim görmektedir.

\subsection{Veri Toplama Araçları}

Araştırmada Algılanan Gelecekteki İstihdam Edilebilirlik Ölçeği (AGİEÖ), Kariyer Sıkıntısı Ölçeği (KSÖ), Kariyer Uyum Yetenekleri ÖlçeğiKisa Form (KUYÖ-KF) ve demografik bilgi formu kullanılmıştır.

\subsubsection{Algılanan Gelecekteki İstihdam Edilebilirlik Ölçeği (AGIEÖ)}

Algılanan Gelecekteki İstihdam Edilebilirlik Ölçeği (AGİË) Gunawan ve diğerleri (2019) tarafindan genç yetişkinlerin gelecekteki istihdam edilebilirliklerine ilişkin algılarını ölçmek üzere geliştirilen öz bildirime dayalı bir ölçme aracıdır (Ek-5). Gelecekteki istihdam edilebilirliklerine ilişkin algılar, öğrencilerin eğitimlerini tamamladıklarında çalışma yaşamına girme eşiğindeyken gelecekte sahip olacakları beceriler, deneyimler, ilişki ağları, kişisel özellikler, çalışma/iş gücü piyasası hakkındaki bilgiler, okulunun/kurumunun itibarı hakkındaki algıları içerir. Ölçek 6'lı Likert tipi "Kesinlikle Katılmiyorum (1), "Kesinlikle Katıliyorum (6)" 
arasında değişen bir derecelemeye göre cevaplandırılmaktadır. Ölçekteki puanlar, maddelere verilen cevapların değerleri toplanarak hesaplanmaktadır. Ölçekten alınan yüksek puan, genç yetişkinlerin iş/çalışma yaşamına hazır ve kendi kariyer planlamasına ve geleceğine dair görüşlerinin olumlu olduğunu bildirmektedir. Ölçek altı faktörlü bir yap1 göstermektedir. Ölçeğin alt boyutları; algılanan gelecekteki iletişim ağı, algılanan gelecekteki deneyimler, algılanan gelecekteki kişisel özellikler, eğitim kurumunun beklenen itibarı, algılanan gelecekteki iş gücü piyasası bilgisi ve algılanan gelecekteki beceriler şeklinde sıralanmaktadır. Ölçekten örnek bazı maddeler şu şekildedir; "İşimde başarılı olmak için kurduğum ilişkilerden yararlanabileceğim. (algılanan gelecekteki iletişim ağı)", "Gelecekteki işverenlerim kazandığım iş deneyimlerinden memnun olacaklar. (algilanan gelecekteki deneyimler)", "Sicilim (kayıtlarım), güçlü bir iş etiğine sahip olduğumu gösterecektir. (algılanan gelecekteki kişisel özellikler)", "Eğitim aldığım üniversitenin itibarı, iş ararken bana çok önemli bir kazanç sağlayacak. (eğitim kurumunun beklenen itibarı)", "Benim için mevcut olan çeşitli iş firsatlarına hâkim olacağım. (algılanan gelecekteki iş gücü piyasası bilgisi)", "Gelecekteki işverenlerim, istedikleri bilgileri ve alana uygun özel/teknik becerileri öğrenmiş olacağımı görecekler. (algilanan gelecekteki beceriler)". Ölçeğin geliştirilme sürecinde yapılan AFA sonrası 24 madde ve altı boyuttan (her boyutta dörder madde olacak şekilde) oluşan bir yapi elde edilmiştir. 24 maddenin toplam varyansın \%79.03'ünü açıkladığı hesaplanmıştır. Faktör yük değerlerinin $\quad .53$ ile .95 arasında dağıldı ${ }_{1}$ görülmüștür. Daha sonra yapılan Doğrulayıcı Faktör Analizinde (DFA) dört farklı model test edilmiştir. DFA'da test edilen dört farklı modelden üçünün, ölçeğin AFA sonrası ortaya çıkan yapıyı doğruladığı bulunmuştur. Altı faktörlü birinci düzey model için $\chi 2=529.6, \mathrm{p}<.001, \mathrm{df}=237, \chi 2 / \mathrm{df}=2.2$, $\mathrm{CFI}=.94$, RMSEA $=.07, \mathrm{AIC}=655.63$; altı faktörlü ikinci düzey model için $\chi 2=563.8, \mathrm{p}<.001, \mathrm{df}=246$, $\chi 2 / \mathrm{df}=2.3, \quad \mathrm{CFI}=.94, \quad \mathrm{RMSEA}=.07, \quad \mathrm{AIC}=671.78$; bifaktör model için $\chi^{2}=471.6, \mathrm{p}<.001, \mathrm{df}=228$, $\chi^{2} / \mathrm{df}=2.1, \quad$ CFI $=.95, \quad \mathrm{RMSEA}=.06, \quad \mathrm{AIC}=615.59$ olarak hesaplanmıştır. Tüm maddelerin genel bir boyutta olduğu model ise yeterli uyum iyiliği değerlerine sahip bulunamamıştır $\quad(\chi 2=2432.9$, $\mathrm{p}<.001, \mathrm{df}=252, \chi 2 / \mathrm{df}=9.6, \mathrm{CFI}=.55, \mathrm{RMSEA}=.19$, $\mathrm{AIC}=2528.95$ ). Ölçeğin uyum geçerliği kapsamında yapılan analiz sonucunda AGİEÖ ile Kariyer Hırsı Ölçeği (Rothwell vd., 2009) ve Üniversiteye Bağllilı Ölçeği (Rothwell vd., 2008) arasında pozitif (sırasiyla, $\mathrm{r}=.65, \mathrm{p}<.001$ ve $\mathrm{r}=.59, \mathrm{p}<.001$ ), Kariyer Sıkıntısı Ölçeği (Creed, Hood, Praskova \& Makransky, 2016) ile negatif $(r=-.39, p<.001)$ bir ilişki bulunmuştur. Ölçeğin hesaplanan iç tutarlık katsayısı ölçeğin tamamı için .95 , algılanan gelecekteki beceriler alt boyutu için .88, algılanan gelecekteki deneyimler için .92, algılanan gelecekteki kişisel özellikler için .88, algılanan gelecekteki iletişim ağı için .95, algılanan gelecekteki iç gücü piyasası bilgisi için .91 ve eğitim kurumunun beklenen itibarı için .89 olarak hesaplanmıştır.

\subsubsection{Kariyer Sıkıntısı Ölçeği (KSÖ)}

Creed ve diğerleri (2016) tarafindan genç yetişkinler üzerinde geliştirilen Kariyer Sıkıntısı Ölçeği (KSÖ) bireylerin kariyer durumları ile ilgili hissettikleri sıkıntıları belirlemektedir. Altılı Likert tipinde (1=Kesinlikle katılmiyorum, 6=Kesinlikle katıllyorum) 9 madde içermektedir. Şensoy ve Siyez (2018) tarafindan Türkçeye uyarlanan form iki faktör altında 6'lı Likert tipinde 9 madde içermektedir. KSÖ'nün ters puanlanan maddesi bulunmamaktadır. KSÖ'den alınan yüksek puan, kariyer sıkıntısının arttığ anlamına gelmektedir. KSÖ'nün yapı geçerliği için uygulanan Doğrulayıcı Faktör Analizi (DFA) sonuçlarına göre orijinal tek faktörlü yapının iyi uyum indekslerine sahip olmadığ 1 görülmüsşür $\quad\left(\chi 2=210.39, \chi^{2} / \mathrm{df}=7.79\right.$, RMSEA $=.117$, AGFI $=.860$, GFI $=.910$, CFI $=.870$, $\mathrm{SRMR}=.07$ ). Maddeler araştırmacılar tarafindan yeniden gözden geçirilmiş ve KSÖ'nün Türk kültüründe "olumsuz duygular" (madde 1, madde 2, madde 3, madde 4 ve madde 7) ve "algılanan engeller" (madde 5, madde 6, madde 8 ve madde 9) olarak iki alt boyuttan oluşabileceği düşünülmüsstür. İki faktörlü model doğrulayıcı faktör analizine alınmış ve modelin kabul edilebilir sınırlar içerisinde sonuç verdiği görülmüştür $(\chi 2=76.28$, $\chi 2 / \mathrm{df}=2.93$, RMSEA $=.063$, AGFI $=.940$, GFI $=.970$, $\mathrm{CFI}=.950, \mathrm{SRMR}=.041$ ). Ölçeğin geliştirilme çalışmasında tüm ölçek içim hesaplanan Cronbach Alfa iç tutarlık katsayısı .90 , uyarlama çalışmasında ise .81'dir. Uyarlama çalışmasında olumsuz duygular alt boyutu için hesaplanan Cronbach Alfa iç tutarlık katsayısı .81 , algılanan engeller için .65 'tir. Bu araştırma kapsamında DFA için toplanan verilerden, tüm ölçek için hesaplanan Cronbach alfa iç tutarlık katsayısı .84, olumsuz duygular alt boyutu için .79, algılanan engeller alt boyutu için $.75^{\prime}$ tir.

\subsubsection{Kariyer Uyum Yetenekleri Ölçeği-Kısa Formu (KUYÖ-KF)}

Ölçeğin kısa formu 24 maddelik orijinal formunda yer alan tüm alt boyutlardan en yüksek faktör yüküne sahip 3'er maddenin alınmasıyla oluşturulmuştur (Maggiori, Rossier \& Savickas, 2017). Uzun formda olduğu gibi ölçeğin kısa formu da 4 faktör altında toplanmıştır. Iş̧1k ve diğerleri (2018) tarafından Türkçeye uyarlanan kısa form 
dört faktör altında 5'li Likert tipinde (1=Güçlü değil, 5=Çok güçlü) 12 madde içermektedir. 12 maddenin toplamı Kariyer Uyum Yetenekleri Ölçeğinin toplam puanını, alt ölçeklerde yer alan maddelerin puanının toplamı ise her bir alt ölçeğe ait Kariyer Uyum Yetenekleri puanını vermektedir. Ölçek uyarlaması lise öğrencileri, üniversite öğrencileri ve çalışan yetişkinler için ayrı ayrı yapılmıştır. Yapılan geçerlik ve güvenirlik çalışmalarında uyarlanan ölçeğin tüm çalışma gruplarında kabul edilebilir geçerlik ve güvenirlik değerlerine sahip olduğu görülmüştür. Üniversite öğrencileri çalışma grubunda tüm ölçeğe ait hesaplanan Cronbach alfa iç tutarlık katsayısı .90, alt boyutlardan ilgi için .79, kontrol için .77, merak için .76 ve güven için .79'dur. $\mathrm{Bu}$ araştırma kapsamında DFA için toplanan verilerden, tüm ölçek için hesaplanan Cronbach alfa iç tutarlık katsayısı .88, alt boyutlardan ilgi için .77, kontrol için .72, merak için .77 ve güven için .69 olarak belirlenmiştir.

\subsubsection{Demografik Bilgi Formu}

Öğrencilerin yaş, cinsiyet, sınıf, fakülte ve ailenin algılanan sosyo-ekonomik durumuna ilişkin soruların yer aldığı ve araştırmacılar tarafından geliştirilen formdur.

\section{3. Çeviri Çalışması}

Ölçeğin Türkçeye uyarlanması için öncelikle ölçeğin geliştirildiği çalışmanın sorumlu yazarı olan Gunawan'la e-posta yoluyla iletişime geçilmiş ve uyarlama çalışması için izin alınmıştır. İzin alındıktan sonra ölçeğin dil geçerliğini sağlamak için öncelikle İngilizce öğretmeni iki kişi ve rehberlik ve psikolojik danışmanlık alanında akademisyen bir kişi ve aynı alanda uzman ve İngilizceye hâkim bir kişi olmak üzere toplamda dört kişi tarafindan birbirinden bağımsız olarak ölçek Türkçeye çevrilmiştir. Yapılan çeviriler daha sonra araştırmacılar tarafindan bir araya getirilerek uzman görüşü için hazırlanmıştır. Bir araya getirilen çeviriler rehberlik ve psikolojik danışmanlık alanında uzman ve iyi düzeyde İngilizce bilgisi bulunan iki akademisyene, çevirilerin özgün maddeleri içerik ve anlam olarak ne kadar karşıladığını değerlendirme ve düzeltme için gönderilmiştir. Çevirilerin kapsam geçerliğini (content validity) sağlamak için Davis tekniği kullanılmıştır (Karakoç \& Dönmez, 2014). Bu tekniğe göre ölçekteki çevrilen maddeler uygun, madde hafifçe gözden geçirilmeli, madde ciddi olarak gözden geçirilmeli ve madde uygun değil şeklinde derecelendirilerek uzmanlar tarafindan değerlendirilmektedir. Değerlendirme sonucunda uzmanların maddelerin en az \%80'i için uygun veya madde hafifçe gözden geçirilmeli şeklinde görüş bildirmeleri kapsam geçerliğini sağlamak için yeterli kabul edilmektedir Uzmanların değerlendirmeleri sonucunda maddelerin \% 62.5'i için uygun, \% 37.5'i için madde hafifçe özden geçirilmeli sonucuna ulaşılmıştır. Uzmanlarca maddelerin herhangi birisi için madde uygun değil değerlendirmesi yapılmamıştır. Elde edilen sonuçlara göre ölçekteki maddelerin Türkçe formu için kapsam geçerliğini sağladığı söylenebilir. Ayrıca akademisyenlerin önerileri doğrultusunda çevirilerdeki bazı kelimeler alan yazınla uyumlu olacak şekilde düzenlenmiștir. Araştırma kapsamında uygulamalara başlamadan önce ölçekteki maddelerin Türkçe dil bilgisi ve yazımı açısından incelenmesi için Türk dili uzmanından görüş alınmıştır. Maddelerin Türkçeye en uygun şekilde son düzeltmeleri yapılarak ölçeğin Türkçe formunun son hali oluşturulmuştur. Ölçeğin dilsel eşdeğerliğini sağlamak için İngilizce ve Türkçeyi bilen öğrencilere formlar birer hafta arayla uygulanmıştır. Dilsel eş değerliğe ilişkin analiz sonuçları bulgularda verilmiştir.

\subsection{Verilerin Toplanması}

Verileri toplama işlemlerine başlamadan önce verilerin toplandığı dersin sorumlusu öğretim üyelerinden uygulama için izin alınmıştır. Uygulamalara başlamadan önce uygulayıcılar tarafından sınıf ortamında gerekli bilgilendirmeler yapılmıştır. Çalışmaya gönüllü katılmak isteyen ögrencilere uygulama formları dağıtılarak verilerin toplanması sağlanmıştır. Öğrencilerin ölçekleri doldurmaları yaklaşık 10 dakika sürmüştür.

\subsection{Verilerin Analizi}

Ölçekler toplam 461 öğrenci tarafindan doldurulmuştur. Ölçek bataryasında maddelerin özensiz yanıtlandığ1, uygunsuz doldurulduğu ve $\% 5$ 'in üzerinde eksik verisi olan herhangi bir öğrenciye ait ölçek bataryası tespit edilmemiştir. Ölçek bataryasında \%5'in altında eksik veriye sahip olan ölçme bataryaları için kayıp veri (missing value) analizi yapılmış ve kayıp verilerin rastlantısal dağılıp dağılmadığ Yapılan analiz sonucunda kayıp verilerin rastlantısal dağıldığı görülmüş ve kayıp veriler serinin ortalaması alınarak tamamlanmıștır. Mahalonobis uzaklığı hesaplanarak uç değerler incelenmiş ve verilere ait uç değer olmadiğ 1 görülmüştür. Yapısal eşitlik gibi yapılarda çok değişkenli normalliğin incelenmesi gerekmektedir (Seçer, 2017). Saçılma diyagramı matrisi (scatter plot matrix) ile incelenen çok değişkenli normallik ve doğrusallık için matrislerin dağılımlarının elips şeklinde olması yeterli kabul edilmektedir (Çokluk, Şekercioğlu \& Büyüköztürk, 2016). Verilere ait incelenen saçılma diyagramında dağılımların elips 
şeklinde olduğu görülmüştür. Ayrıca tek değişkenli normallik için verilerin basıklık (kurtosis) ve çarpıklık (skewness) değerleri incelenmiştir. DFA, uyum geçerliği, test-tekrar test analizleri için toplanan verilerin basıklık ve çarpıklık değerlerinin +/- 1 arasında dağıldığı görülmüştür. Buna göre dağılımların normal olduğu söylenebilir (Seçer, 2017). Ancak dilsel eş değerliği belirlemek için toplanan veriler incelendiğinde, İngilizce ve Türkçe formlara ait toplam puanların basıklık ve çarpıklık değerlerinin +/- 1 dışında olduğu görülmüştür (İngilizce form: çarp $1 \mathrm{kl} 1 \mathrm{k}=-1.27$, basıklık= 1.37; Türkçe form: çarp $1 \mathrm{kl} 1 \mathrm{k}=-1.14$, basıklık= 1.64). Buna göre dilsel eş değerlik için toplanan verilerin normal dağılım göstermediği söylenebilir.

Ölçeğin madde ayırt ediciliği, uyum geçerliği ve test-tekrar test güvenirlik analizleri için Pearson Momentler Çarpımı korelasyon analizi kullanılmıştır. Dilsel eş değerliği belirlemek için toplanan veriler normal dağılım göstermediğinden dolayı dilsel eş değerliğin analiz edilmesinde Spearman Brown Sıra Farkları korelasyon analizinden yararlanılmıştır. Ölçeğin iç tutarlık güvenirliğinin incelenmesinde Cronbach Alfa katsayısı hesaplanmıştır. Ayrıca ölçeğin yap1 güvenirliği için de Bileşik Güvenirlik katsayısı (CR) hesaplanmıştır. Ölçeğe ait yapının geçerliğinin incelenmesinde DFA yapılmıştır. Yapı geçerliği için ölçeğe ait incelenen modellerde ölçeğin orijinal formunun geliştirilme aşamalarında da kullanılan $\chi 2$ (Ki kare), sd (serbestlik derecesi), $\chi 2 / s d, C F I$, RMSEA, AIC değerleri kullanılmıştır. Modelin uyum iyiliğinin değerlendirilmesinde $\chi 2$ 'nin anlamlı olması, $\chi 2 /$ sd'nin 5 'ten küçük olması (Çokluk vd., 2016; Sümer, 2000), CFI'nin .85 üzerinde olmas1 (Bollen, 1989), RMSEA'nın .10 ve daha düşük olmas1 (Kelloway, 1989; Marcoulides \& Schumacher, 2001; Tabachnick \& Fidell, 2001) kabul edilebilir uyum iyiliğini göstermektedir. Ölçeğe ait yapının incelenmesinde yakınsak geçerlik (convergent validity) ve ayırt edici geçerlik (discriminant validity) de incelenmiştir. Yakınsak geçerlik için Ortalama Açıklanan Varyans (AVE) değerleri hesaplanmış, ayırt edici geçerlik için de faktörler arası korelasyonlar incelenmiştir. Modeller arasındaki farklılığı değerlendirmek için Akaike bilgi kriteri (AIC) kullanılmıştır. AIC'ın düşük değere sahip olması daha iyi uyumun göstergesidir (Hair, Black, Babin \& Anderson, 2010). Analizlerin yapılmasında SPSS 25 ve AMOS 24 istatistik paket programlarından yararlanılmıştır.

\section{BULGULAR}

Uyarlama çalışması için yapılan geçerlik ve güvenirlik analizlerine ilişkin bulgular aşağıda sırasıyla verilmiştir. İlk olarak geçerliğe ilişkin bulgulara yer verilmiştir ve bu kapsamda dil geçerliği, yapı geçerliği, uyum geçerliği ve madde analizi bulguları sunulmuştur. Daha sonra güvenirlik bulgularına yönelik olarak iç tutarlık ve test-tekrar test güvenirlik katsayıları verilmiştir.

\section{1. Ölçeğin Geçerliğine İlişkin Bulgular}

Dil Geçerliği: Ölçeğin dil geçerliğini belirlemek için istatistiksel uygulama yöntemi kullanılmıştır. $\mathrm{Bu}$ yöntemde İngilizceye hâkim örneklem grubuna bir hafta arayla ölçeğin İngilizce ve Türkçe formları uygulanmaktadır. Uygulamalardan sonra ise aynı kişilere ait ölçek formları arasındaki korelasyon değerleri hesaplanmaktadır (Seçer, 2015). Öncelikle ölçeğin orijinal İngilizce formu İngilizce bilen 20 öğrencinin tamamına uygulanmıştır. Bir hafta sonra ise aynı öğrenci grubuna ölçeğin Türkçe formu uygulanmıştır. Ölçek formlarının toplam puanları arasındaki ilişki Spearman Brown Sıra Farkları korelasyon analizi ile incelenmiştir. Analiz sonucuna göre ölçeğin İngilizce ve Türkçe formları arasındaki ilişkinin anlamlı, pozitif ve yüksek düzeyde $(\mathrm{r}=.80, \quad \mathrm{p}<.001)$ olduğu görülmüştür. Korelasyon değerinin .70 ve üzerinde olması dilsel eş değerliğin sağlandığını göstermektedir (Seçer, 2015).

Yapı Geçerliği: Ölçeğin yapı geçerliğini incelemek için DFA yapılmıştır. Katılımcılara ait verilere ilişkin analizler gerçekleştirirken hiçbir sınırlama ve modifikasyon işlemi yapılmamıştır. Orijinal yapıların Türk örnekleminde de benzer ya da farklı yapılarda olup olmadığını incelemek amacıyla dört farklı model test edilmiştir. Altı boyuttan oluşan altı faktörlü modelde orijinal formdaki gibi her bir gizil değişkene ait dört gözlenen değişken tanımlanmıştır. Tek faktörlü modelde tüm maddeler yalnızca bir gizil değişsken altında toplanmıştır. $\mathrm{Bu}$ modelle tüm maddelerin tek bir gizil değişken tarafından temsil edilip edilmeyeceği incelenmiştir. İkinci düzey altı faktörlü modelde, altı faktörün ikinci düzey tek gizil değișken tarafından temsil edilip edilmediği test edilmiştir. Ölçeğe ait test edilen son model ise bifaktör modeldir. Bu modelde her bir maddenin hem genel faktör hem de ait olduğu faktör altında toplanmasına izin verilmiştir. $\mathrm{Bu}$ model grup faktörlerini kontrol ederken genel faktörlere karşılık gelen ortak madde varyansı oranını değerlendirmiştir.

DFA sonuçlarına ilişkin bilgilerin yer aldığı Tablo 1'e bakıldığında tek faktörlü model dışında kalan modellerin kabul edilebilir uyum değerlerine sahip olduğu söylenebilir. 
Tablo 1: DFA sonrası modellere ait uyum iyiliği değerleri

\begin{tabular}{lcccccc}
\hline Model & $\chi^{\mathbf{2}}$ & sd & $\chi^{\mathbf{2} / \text { sd }}$ & CFI & RMSEA & AIC \\
\hline Altı faktörlü model & $600.344^{*}$ & 237 & 2.53 & .92 & .08 & 726.344 \\
İkinci düzey altı faktörlü model & $752.628^{*}$ & 246 & 3.06 & .89 & .09 & 860.628 \\
Tek faktörlü model & $1649.531^{*}$ & 252 & 6.55 & .69 & .15 & 1745.531 \\
Bifaktör model & $663.259^{*}$ & 228 & 2.10 & .90 & .09 & 807.259 \\
\hline
\end{tabular}

Not: $n=235$. DFA: doğrulayıcı faktör analizi; sd: serbestlik derecesi; CFI: karşılaştırmalı uyum indeksi; RMSEA: yaklaşık hataların ortalama karekökü; AIC: Akaike bilgi kriteri.

${ }^{*} \mathrm{p}<.001$.

Altı faktörlü modelde madde faktör yük değerlerinin .68 ile .91 (Ek-1); ikinci düzey altı faktörlü modelde ise .68 ile .92 (Ek-2) arasinda değiştiği görülmektedir. Tek faktörlü modelde dört maddenin faktör yük değerinin .30 altında kaldığı görülmüştür (Ek-3). Benzer şekilde bifaktör modelde de genel boyuta ilişkin madde faktör yüklerinden dört maddenin .30 ve altında kaldığ görülmüștür. Ayrıca her faktör altında ayrı ayrı hesaplanan madde faktör yük değerleri incelendiğinde ise altı gözlenen değişkene ait faktör yük değerlerinin .30 altında kaldığı görülmüştür (Ek-4).

AIC değeri göz önüne alındığında en iyi uyumu gösteren modelin altı faktörlü model olduğu görülmektedir. İkinci düzey altı faktörlü modelin madde faktör yük değerleri ve uyum değerleri göz önüne alındığında, bu modelin de kullanılabileceği söylenebilir. Dolayısıyla altı faktör, ikinci düzey tek faktör tarafindan da temsil edilebilmektedir. Buradan hareketle ölçeğe ait alt boyutların toplam puanlarının kullanılmasının yanı sıra ölçeğin toplam puanının da kullanılabileceği söylenebilir. Bifaktör modele ait analiz sonuçları incelendiğinde; modelin kabul edilebilir uyum iyiliği değerlerine sahip olmasının yanı sıra madde faktör yük değerlerinin .30 altında kaldığı görülmüştür. $\mathrm{Bu}$ durum, modelden ilgili maddelerin çıkarılıp yeniden analiz yapılması ihtiyacını ortaya çıkarmıştır. Çünkü madde faktör yük değeri .30 sinırına kadar inebilmekte ve bu değerin altındaki değerler modelde kabul edilmemektedir (Büyüköztürk, 2014; Seçer, 2015). Yapılan analizlerde daha iyi uyum iyiliği değerlerine sahip olan modeller olduğundan dolayı modele ilişkin analizler sürdürülmemiştir.

Yap1 geçerliğinin incelenmesinde başka bir yöntem olan yakınsak geçerlik için AVE değeri hesaplanmıştır. Yapılan hesaplamalar sonucunda ölçeğin algılanan gelecekteki iletişim ağı alt boyutu için .54, algılanan gelecekteki deneyimler alt boyutu için .71, algılanan gelecekteki kişisel özellikler alt boyutu için .63, eğitim kurumunun beklenen itibarı alt boyutu için .66, algılanan gelecekteki iş gücü piyasası bilgisi alt boyutu için .68 , algılanan gelecekteki beceriler alt boyutu için .74 olarak AVE değerleri belirlenmiştir. Yakınsak geçerlik için her bir faktöre ait hesaplanan AVE değerinin .50 ve üzerinde olması yeterli görülmektedir (Fornell \& Larcker, 1981; Hair vd., 2010). Hesaplanan AVE değerleri incelendiğinde, alt boyutlara ilişkin AVE değerlerinin yakınsak geçerliği sağladığı söylenebilir. Bunun yanı sıra ayırt edici geçerliğgin değerlendirilmesinde alt boyutlar arasındaki korelasyon değerleri incelenmiştir. Kline'a (2005) göre ayırt edici geçerliğin sağlanmasında faktörler arası korelasyonların .85 ve üzerinde olmaması gerekmektedir. Tablo 2 incelendiğinde faktörler arası korelasyonların .85 düzeyinden düşük olduğu görülmektedir. Dolayısıyla ölçeğin yapısıyla ilgili olarak ayırt edici geçerliğin sağlandığı söylenebilir.

Uyum Geçerliği: Uyum geçerliği çalı̧̧ması kapsamında ölçeğin Kariyer Stresi Ölçeği ile Kariyer Uyum Yetenekleri Ölçeğine ilişkin puanlar arasındaki ilişkiler incelenmiştir. Tablo 2 'de de görüleceği üzere, Algılanan Gelecekteki İstihdam Edilebilirlik Ölçeğinin toplam ve alt boyut puanları ile Kariyer Uyum Yetenekleri Ölçeğinin toplam ve alt boyut puanları arasında pozitif ve anlamlı ilişkiler olduğu bulunmuştur. Yalnızca kariyer uyum yeteneğinin kontrol alt boyutu ile algılanan gelecekteki istihdam edilebilirliğin eğitim kurumunun beklenen itibarı arasında anlamlı ilişki bulunamamıştır. Diğer yandan Algılanan Gelecekteki İstihdam Edilebilirlik Ölçeğinin eğitim kurumunun beklenen itibarı alt boyutu ile Kariyer Stresi Ölçeğinin toplam ve olumsuz duygular alt boyutu arasında negatif, düşük düzeyde anlamlı ilişkiler bulunmuştur.

\section{2. Ölçeğin Güvenirliğine İlişsin Bulgular}

Ölçeğin güvenirliğine ilişkin yapılan çalışmada yapı güvenirliğini incelemek için Bileşik Güvenirlik 
Tablo 2: Ölçek ve alt boyutlara ilişkin korelasyon değerleri

\begin{tabular}{|c|c|c|c|c|c|c|c|c|c|c|c|c|c|c|c|}
\hline & & 1 & 2 & 3 & 4 & 5 & 6 & 7 & 8 & 9 & 10 & 11 & 12 & 13 & 14 \\
\hline 1. & Agia & & & & & & & & & & & & & & \\
\hline 2. & Agd & $.69^{* * *}$ & & & & & & & & & & & & & \\
\hline 3. & Agkö & $.69^{* * *}$ & $.82^{* * * *}$ & & & & & & & & & & & & \\
\hline 4. & Ekbi & $.27^{* *}$ & $.20^{*}$ & $.22^{* *}$ & & & & & & & & & & & \\
\hline 5. & Agigpb & $.71^{* * * *}$ & $.68^{\text {**** }}$ & $.70^{* * * *}$ & $.18^{*}$ & & & & & & & & & & \\
\hline 6. & Agb & $.70^{* * *}$ & $.76^{* * * *}$ & $.70^{* * * *}$ & $.19^{*}$ & $.84^{* * *}$ & & & & & & & & & \\
\hline 7. & AgieTop & $.84^{* * * *}$ & $.87^{* * * *}$ & $.86^{* * *}$ & $.47^{* * * *}$ & $.85^{* * * *}$ & $.87^{* * * *}$ & & & & & & & & \\
\hline 8. & Od & .04 & .06 & .05 & $-.17^{*}$ & .04 & .09 & .02 & & & & & & & \\
\hline 9. & $\mathrm{Ae}$ & -.01 & -.05 & -.08 & -.15 & -.12 & -.06 & -.10 & $.61^{* * *}$ & & & & & & \\
\hline 10. & KsTop & .02 & .02 & -.01 & $-.18^{*}$ & -.03 & .03 & -.04 & $.92^{* * *}$ & $.87^{* * *}$ & & & & & \\
\hline 11. & İlgi & $.19^{*}$ & $.29^{* * * *}$ & $.25^{* * *}$ & $.24^{*}$ & $.27^{* *}$ & $.32^{* * * *}$ & $.33^{* * *}$ & $-.33^{* * *}$ & $-.50^{* * *}$ & $-.45^{* * *}$ & & & & \\
\hline 12. & Kontrol & $.26^{* *}$ & $.24^{* * *}$ & $.27^{* * *}$ & .09 & $.23^{* *}$ & $.25^{* *}$ & $.28^{* * *}$ & $-.34^{* * *}$ & $-.45^{* * *}$ & $-.43^{\text {**** }}$ & $.54^{* * *}$ & & & \\
\hline 13. & Merak & $.34^{* * *}$ & $.33^{\text {**** }}$ & $.32^{* * * *}$ & $.20^{*}$ & $.34^{* * *}$ & $.32^{* * * *}$ & $.40^{* * * *}$ & $-.27^{* * *}$ & $-.37^{* * *}$ & $-.35^{* * * *}$ & $.58^{* * *}$ & $.62^{* * *}$ & & \\
\hline 14. & Güven & $.27^{* *}$ & $.32^{* * * *}$ & $.33^{\text {**** }}$ & $.19^{*}$ & $.37^{* * *}$ & $.39^{* * *}$ & $.39^{* * *}$ & $-.22^{* *}$ & $-.31^{* * *}$ & $-.29^{* * *}$ & $.46^{* * *}$ & $.45^{* * *}$ & $.66^{* * * *}$ & \\
\hline 15. & KuyTop & $.32^{* * *}$ & $.36^{* * * *}$ & $.36^{* * * *}$ & $.22^{* *}$ & $.37^{* * *}$ & $.39^{* * *}$ & $.43^{* * *}$ & $-.36^{* * *}$ & $-.51^{* * *}$ & $-.47^{* * *}$ & $.80^{* * *}$ & $.81^{* * *}$ & $.87^{* * *}$ & $.77^{* * *}$ \\
\hline
\end{tabular}

$\mathrm{n}=146$

Not1: *p $<.05 ; * * \mathrm{p}<.01 ; * * * \mathrm{p}<.001$

Not2: Agia: Algılanan gelecekteki iletişim ağı; Agd: Algılanan gelecekteki deneyimler; Agkö: Algılanan gelecekteki kişisel özellikler; Ekbi: Eğitim kurumunun beklenen itibarı; Agigpb: Algılanan

gelecekteki iş gücü piyasası bilgisi; Agb: Algılanan gelecekteki beceriler; AgieTop: Algılanan gelecekte istihdam edilebilirlik toplam puanı; Od: Kariyer sıkıntısı alt boyutu olumsuz duygular; Ae: Kariyer sıkıntısı alt boyutu algılanan engeller; KsTop: Kariyer sıkıntısı toplam puanı; KuyTop: Kariye uyum yetenekleri toplam puanı. 
katsayısı (CR), Cronbach Alpha iç tutarlılık katsayısı, üç hafta arayla uygulanan test-tekrar test uygulamalarından elde edilen puanların test-tekrar test korelasyonları hesaplanmış ve madde ayırıcılı̆̆ için de madde analizi yapılmıştır. Ölçeğin toplam ve alt boyutlarına ilişkin hesaplanan CR katsayıları, Cronbach Alpha iç tutarlılık katsayıları ve testtekrar test korelasyonları Tablo 3 'te sunulmuştur.

Tablo 3'te de görüleceği üzere ölçeğin alt boyutlarına ilişkin hesaplanan CR değerleri .82 ile .92 arasında değişmektedir. CR değerlerinin .70 ve üzerinde olması yap1 güvenirliğinin sağlanmasında yeterli olarak kabul edilmektedir (Hair vd., 2010). Dolayısıyla ölçeğin yapı güvenirliğinin sağlandığ söylenebilir. Ölçeğin toplam ve alt boyutlarına ilişkin hesaplanan Cronbach Alpha iç tutarlılık katsayıları .82 ile .95 arasında değişmektedir. Hesaplanan iç tutarlık katsayılarının .70 ve üzerinde olmasından dolayı ölçeğin toplam ve alt boyutlarına ilişkin güvenirliğin yeterli düzeyde olduğu söylenebilir (Landis \& Koch, 1977; Robinson, Shaver \& Wrightsman, 1991). Ölçeğin üç hafta arayla uygulanmasıyla elde edilen puanlar arasındaki korelasyonların toplam ölçek için .70, alt boyutlar için de .37 ile .63 arasında olduğu görülmektedir. AGİEÖ'nün madde ayırıcılığını incelemek için yapılan madde analizi sonucunda ise madde-toplam puanı arasındaki korelasyonun .41 ile .83 arasında değiştiği görülmüştür. Maddetoplam korelasyonunun .30 ve üzerinde olmasının yeterli düzeyde ayırt ediciliğe sahip olduğu göz önünde bulundurulduğunda, ölçek maddelerinin yeterli ayırt ediciliğe sahip olduğu söylenebilir (Büyüköztürk, 2014).

\section{TARTIŞMA ve SONUÇ}

$\mathrm{Bu}$ araştırmada Gunawan ve diğerleri (2019) tarafindan genç yetişkinlerin gelecekteki istihdam edilebilirliklerine ilişkin algılarını ölçmek üzere geliştirilen Algılanan Gelecekteki İstihdam
Edilebilirlik Ölçeği Türkçeye uyarlanmış olup geçerlik ve güvenirliğine ilişkin psikometrik özellikleri incelenmiştir. Araştırmada, iş gücü piyasasına adım atmak üzere olan genç yetişkinlerin; gelecekteki becerileri, deneyimleri, iletişim ağları, kişisel özellikleri, işgücü piyasası hakkındaki bilgileri ve örgün eğitimlerini tamamlayacakları üniversitenin kurumsal itibarı hakkındaki algılarını ilgilendiren bir ölçme aracının uyarlanması hedeflenmiştir.

Dilsel eşdeğerliğin belirlenmesi için yapılan korelasyon analizinde, ölçeğin Türkçe ve İngilizce formlarından elde edilen toplam puanlar arasında pozitif ve yüksek düzeyde anlamlı ilişki bulunmuştur. Yapı ve uyum geçerliği ile dilsel eşdeğerliğe ilişkin bu bulgular, AGİEÖ’nün Türkçe formunun geçerlik kriterlerinin önemli bir kısmını sağladığına işaret etmektedir. AGİË̈nün güvenirliğine ilişkin yapılan analizler sonucunda, ölçeğin hem alt boyutlar hem de toplam puan açısından hesaplanan iç tutarlık katsayılarının kabul edilebilir güvenirlik değerlerini karşıladığı görülmüştür. Araştırmadan elde edilen sonuçlara göre ölçeğin Türkçe formunun üniversite öğrencilerinde kullanılabilir olduğu söylenebilir.

Ölçeğin altı faktörlü yapısının model uyumu birinci ve ikinci düzey DFA ile test edilmiştir. Birinci ve ikinci düzey DFA sonucunda Algılanan Gelecekteki İstihdam Edilebilirlik Ölçeği'nin (AGİEÖ) altı faktörlü yapısının model uyum indekslerinin iyi düzeyde olduğu bulunmuştur. Ayrıca AİGEÖ'nün madde faktör yük değerlerinin tüm alt boyutlarda kabul edilebilir düzeylerde olduğu görülmüştür. Elde edilen faktör yük değerlerinin yeterli düzeyde olduğu ve AİGEÖ'nün özgün formunda sahip olduğu altı faktörlü yapısının Türk örneklem üzerinde de korunduğu söylenebilir.

Uyum geçerliği kapsamında yapılan korelasyon analizinde AGİEÖ'nün Kariyer Uyum Yetenekleri Ölçeği ile pozitif ve orta düzeyde ilişkiye sahip olduğu görülmüştür. Diğer yandan Kariyer Sıkıntısı

Tablo 3: AGIEÖ toplam ve alt boyutlara ilişkin Cronbach Alpha ve test-tekrar test korelasyon değerleri

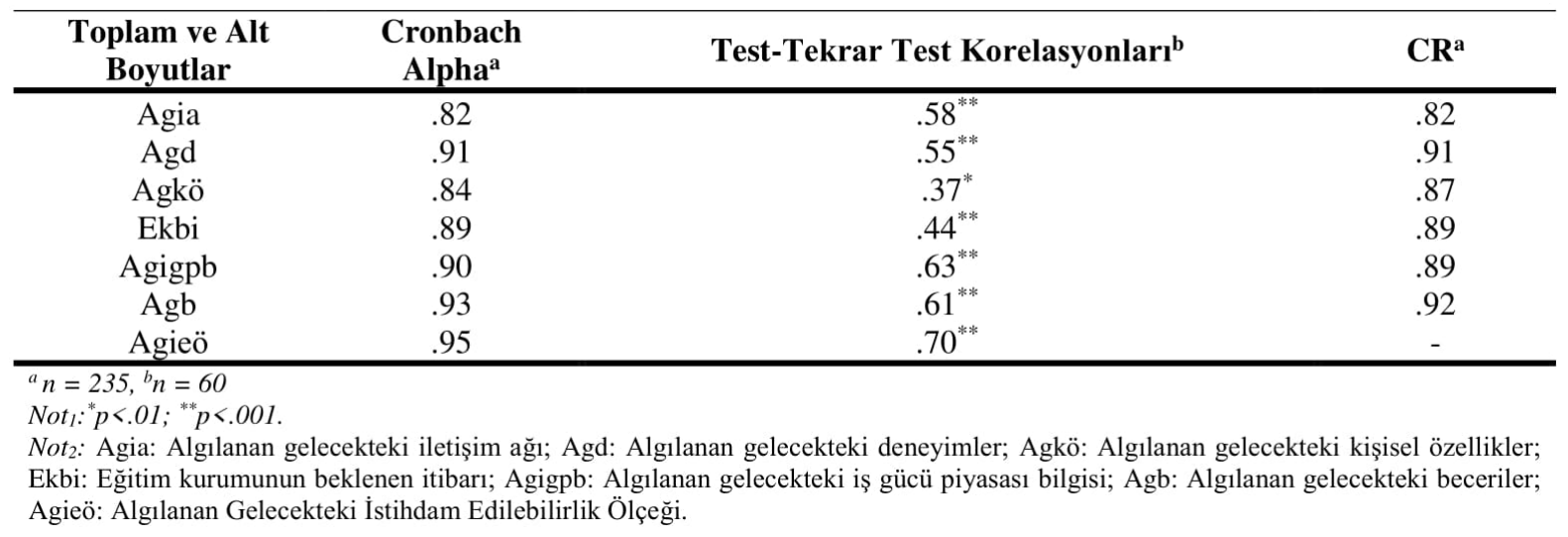


Ölçeği toplam puanı ve olumsuz duygular alt boyutu ile AGİÖ'nün eğitim kurumunun beklenen itibarı alt boyutu arasında anlamlı negatif ve düşük düzeyde anlamlı ilişkiler bulunmuştur. Bu sonuçlara benzer şekilde Gunawan ve diğerleri (2019) ölçeğin geliştirme çalışmasında Kariyer Sıkıntısı Ölçeği toplam puanı ve AGİEÖ'nün toplam puanı arasında negatif yönde zayıf bir ilişkinin olduğunu ortaya koymuştur. Kariyer sıkıntısı, kariyer karar verme sürecine yönelik olumsuz duygular yansitmaktadır (Larson, Toulouse, Ngumba, Fitzpatrick, \& Heppner, 1994). Bu sebeple algilanan gelecekte istihdam edilebilirlikle olumsuz yönde ilişskilendiği düşünülmektedir. Diğer yandan kariyer uyum yeteneğinin bireyin kariyerinde karşılaştı̆̆ güçlüklerle başa çıkabilme kapasitesi olduğu düşünüldüğünde (Maggiori vd., 2017), kariyer uyum yetenekleri ile algilanan gelecekteki istihdam edilebilirlik arasındaki pozitif ilişkinin uyumlu olduğu söylenebilir.

Uyarlanan bu ölçeğin üniversitelerin psikolojik danışma merkezleri, akademik danışmanlar, kariyer danışmanları, öğrenci işleri personeli, insan kaynakları uzmanları ve kendilerini istihdam edilmeye hazırlayan öğrencilerle çalışan diğer uzmanlar tarafindan kullanılabileceği düşünülmektedir. $\mathrm{Bu}$ durum, öğrencilerin geleceklerine ilişkin görüşlerinin sorunlu yönlerini geliştirmelerine katkı sunabilir. Ayrıca öğrencilerin algılanan istihdam edilebilirliklerini anlamak amacıyla yapılacak çalışmalarda bireyin kariyerinde ön gördüğü ya da ön göremediği problemlerle başa çıkabilme kapasitesi olan kariyer uyum yetenekleri veya kariyer hedefinin uygunluğu, hedefe yönelik ilerlemenin yeterliliği ve hedeflere ulaşmak için hangi değişikliklerin yapılması gerektiği hakkında bilgi sağlayan kariyer hedefi geri bildirimleri gibi kavramlarla da ilişkisinin anlaşılmasına ihtiyaç duyulduğu söylenebilir. Bunun yanı sıra öğrencilerin istihdam edilebilirliğini arttırmak için hedeflenmiş etkili strateji ve deneysel çalışmalar aracılığıyla öğrencilerin algılanan istidam edilebilirlik becerilerine yönelik çalışmalar yapilabilir.

$\mathrm{Bu}$ çalışmada bazı sınırlılıklar bulunmaktadır. Ölçeğin uyarlanması Türkiye'de bulunan iki üniversiteden toplanan verilerle gerçekleştirilmiştir. İleride yapılacak çalışmalarda, farklı üniversitelerdeki örneklemlerde yapılacak geçerlik ve güvenirlik analizleri ölçeğin diş geçerliğini arttıracaktır. Çalışmaya katılan öğrencilerin çoğunluğu kendini orta düzeyde sosyoekonomik düzeye sahip görmektedir. Yapılacak çalışmalarda ve araştırmanın sonucunun genellenmesinde bu sınırlılık da göz önünde bulundurulmalıdır. Ayrıca bu çalışmada, ölçeğin ölçme değişmezliği incelenmemiştir. Algılanan gelecekteki istihdam edilebilirlikte ayırt edici olabilecek cinsiyet ve sosyoekonomik düzeylere göre ölçeğin ölçme değişmezliği incelenebilir.

\section{ETIKK BEYANATI}

Destek Bilgisi: $\mathrm{Bu}$ araştırma için herhangi bir resmi, özel kurum veya organizasyondan destek alınmamıştır.

Çıkar Çatışması: Tüm yazarlar adına, sorumlu yazar çıkar çatışması olmadığını belirtir.

Etik Onayı: İnsan katılımcıları içeren çalışmalarda gerçekleştirilen tüm prosedürler, kurumsal ve / veya ulusal araştırma komitesinin etik standartlarına ve 1964 Helsinki deklarasyonuna ve daha sonraki değişikliklerine veya karşılaştırılabilir etik standartlara uygundur.

Bilgilendirilmiş Onam Formu: Araştırmaya katılan tüm bireyler, araştırmanın içeriği ve araştırmanın gönüllülük esasına dayalı olarak yürütüldügüne dair bilgilendirilmiş onam formu ile aydınlatılmıştır. 


\section{KAYNAKÇA}

Bernston, E., Sverke, M. \& Marklund, S. (2006). Predicting Perceived Employability: Human Capital or Labour Market Opportunitiesi. Economic and Industrial Democracy, 27(2), 223-244.

Berntson, E. \& Marklund, S. (2007). The relationship between perceived employability and subsequent health. Work and Stress, 21, 279-292. doi:10.1080/02678370701659215

Bollen, K. A. (1989). Structural equations with latent variables. New York: Wiley.

Büyüköztürk, Ş. (2014). Sosyal Bilimler Iç̧in Veri Analizi El Kitabı (20. Bask1.). Ankara: Pegem Akademi.

Castells, M. (2000). The information age: Economy, society and culture. Oxford, UK: Blackwel Publishers.

Clarke, M. (2008). Understanding and managing employability in changing career contexts. Journal of European Industrial Training, 32(4), 258-284.

Creed, P. A., Hood, M., Praskova, A. \& Makransky, G. (2016). The career distress scale: Using Rasch measurement theory to evaluate a brief measure of career distress. Journal of Career Assessment, 24, 732-746. doi:10.1177/1069072715616126

Cross, S. \& Markus, H. (1991). Possible selves across the life-span. Human Development, 34, 225-230. doi:10. $1159 / 000277058$

Cuyper, N. D., Claudia, B. O., Bernston, E., O., Eric B. \& Alarco H. (2008). Employability and Employees Well-Being: Mediation by Job Insecurity. Applied Psychology: An International Review, 57(3), 488-509.

Çokluk, Ö., Şekercioğlu, G., \& Büyüköztürk, Ş. (2016). Sosyal Bilimler Iç̧in Çok Değişkenli İstatistik SPSS ve LISREL Uygulamalart (4. Bask1.). Ankara: An1 Yayınc1lık.

Ellen, P. S., Wiener, J. L. \& Fitzgerald, M. P. (2012). Encouraging people to save for their future: Augmenting current efforts with positive visions of the future. Journal of Public Policy \& Marketing, 31, 58-72. doi:10.1509/jppm.09.089

Fornell, C., \& Larcker, D. F. (1981). Evaluating structural equation models with unobservable variables and measurement error. Journal of Marketing Research, 18(1), 39-50. https://doi.org/10.2307/3151312

Forrier, A. \& Sels, L. (2003). The concept employability: A complex mosaic. International Journal of Human Resources Development and Management, 3, 102124.
Gazier, B. (1998). Employability: Definitions and trends. In B. Gazier (Ed.), Employability: Concepts and Policies (ss. 37-71). Berlin, Germany: European Employment Observatory.

Gerçek, M. \& Atay, S. E. (2017). Rothwell ve Arnold'ın Algılanan İstihdam Edilebilirlik Ölçeğinin Türkçe'ye Uyarlama, Geçerlilik ve Güvenirlik Çalışması. Dumlupınar Üniversitesi SBE Dergisi, (54), 91-103.

Guilbert, L., Bernaud, J., Gouvernet, B. \& Rossier, J. (2016). Employability: Review and research prospects. International Journal for Educational and Vocational Guidance, 16, 69-89. doi:10.1007/s10775-015-9288-4

Gunawan, W., Creed, P. A., \& Glendon, A. I. (2019). Development and initial validation of a Perceived Future Employability Scale for young adults. Journal of Career Assessment, 27(4), 610 627. https://doi.org/10.1177/1069072718788645

Hair, J. F., Black, W. C., Babin, B. J. \& Anderson, R. E. (2010). Multivariate data analysis. A global perspective. NJ: Printice Hall.

Harvey, L. (2001). Defining and measuring employability. Quality in Higher Education, 7, 97110. doi:10.1080/13538320120059990

Hesselink, D. J. K. \& Van Vuuren, T. (1999). Job flexibility and job insecurity: the Dutch case. European Journal of Work and Organizational Psychology, 8, 273-293.

Hillage, J. \& Pollard, E. (1998). Employability: Developing a framework for policy analysis. (Research report RR85). Brighton, England: Institute for Employment Studies. Retrieved from https://goo.gl/z68mlS

Hiltrop, J. M. (1995). The changing psychological contract: the human resource challenge of the 1990s. European Management Journal, 13, 286-294.

Hirsch, J. (1991) 'From the Fordist to the Post-Fordist State. In, B. Jessop, H. Kastandiek, K. Nielsen \& O. K. Pedersen (Eds), The Politics of Flexibility: Restructuring State and Industry in Britain, Germany and Scandinavia. Aldershot: Elgar Publishing.

Işık, E., Yeğin, F., Koyuncu, S., Eser, A., Çömlekciler, F., \& Yildırım, K. (2018). Validation of the Career Adapt-Abilities Scale-Short Form across different age groups in the Turkish context. International Journal for Educational and Vocational Guidance, 18(3), 297-314. https://doi.org/10.1007/s10775-0189362-9

Kalleberg, A. L. (2001). Organizing Flexibility: The Flexible Firm in a New Century. British Journal of Industrial Relations, 39(4), 479-504. 
Karakoç, F. Y. \& Dönmez, L. (2014). Ölçek geliştirme çalışmalarında temel ilkeler. Tıp Eğitimi Dünyası, 40, 39-49.

Kelloway, K. E. (1989). Using Lisrel for Structural Equation Modeling: A Researcher's Guide (Sage.). London.

Kline, R. B. (2005). Methodology in the social sciences. Principles and practice of structural equation modeling (2nd ed.). Guilford Press.

Knight, P. \& Yorke, M. (2004). Learning, curriculum and employability in higher education. London, England: Routledge Falmer.

Landis, J. R. \& Koch, G. G. (1977). The measurement of observer agreement for categorical data. Biometrics, $33,159-174$

Larson, L. M., Toulouse, A. L., Ngumba, W. E., Fitzpatrick, L. A., \& Heppner, P. P. (1994). The development and validation of coping with career indecision. Journal of Career Assessment, 2, 91-110. doi:10.1177/ 106907279400200201

Lord, R. G., Diefendorff, J. M., Schmidt, A. M. \& Hall, R. J. (2010). Self-regulation at work. Annual Review of Psychology, 61, 43-568. doi:10.1146/annurevpsych.093308. 100314

Maggiori, C., Rossier, J. \& Savickas, M. L. (2017) Career Adapt-Abilities Scale-Short Form (CAASSF): Construction and validation. Journal of Career Assessment, 25, 312-325. https://doi.org/10.1177/1069072714565856.

Marcoulides, G. \& Schumacher, R. (2001). New Developments and Techniques in Structural Equation Modeling. London: Lawrence Erlbaum Associates Publishers.

Markus, H. \& Nurius, P. (1986). Possible selves. American Psychologist, 41, 954-969. doi:10.1037/0003-066X.41.9.954

Pool, L. D., Qualter, P. \& Sewell, P. J. (2014). Exploring the factor structure of the CareerEDGE employability development profile. Education and Training, 56, 303-313. doi:10.1108/ET-01 2013-0009

Robinson, J. P., Shaver, P. R. \& Wrightsman, L. S. (1991). Criteria for Scale Selection and Evulation in Measure of Personality and Social Psychological Attitudes. San Diego: California Academic Press.

Rothwell, A. \& Arnold, J. (2007). Self-perceived employability: Development and validation of a scale. Personnel Review, 36, 23-41. doi:10.1108/00483480710716704

Rothwell, A., Herbert, I. \& Rothwell, F. (2008). Selfperceived employability: Construction and initial validation of a scale for university students. Journal of Vocational Behavior, 73, 1-12. doi:10.1016/ j.jvb.2007.12.001

Rothwell, A., Jewell, S. \& Hardie, M. (2009). Selfperceived employability: Investigating the responses of post-graduate students. Journal of Vocational Behavior, $\quad 75, \quad 152-161$. doi:10.1016/j.jvb.2009.05.002

Sanders J \& De Grip A (2004) Training, task flexibility and the employability of low-skilled workers. International Journal of Manpower 25(1): 73-89

Seçer, İ. (2015). Psikolojik Test Geliştirme ve Uyarlama Süreci. Ankara: Anı Yayıncılık.

Seçer, İ. (2017). Spss ve Lisrel ile Pratik Veri Analizi Analiz ve Raporlaştırma. Ankara: Anı Yayıncılık.

Sümer, N. (2000). Yapısal Eşitlik Modelleri. Türk Psikoloji Yazıları, 3(6), 49-74.

Silla, I., De Cuyper, N., Gracia, F., Peiro', J. M. \& De Witte, H. (2009). Job insecurity and well-being: Moderation by employability. Journal of Happiness Studies, doi: 10.1007/ s10902-008-9119-0.

Sensoy, G. \& Siyez, D. M. (2018). The career distress scale: structure, concurrent and discriminant validity, and internal reliability in a Turkish sample. International Journal for Educational and Vocational Guidance, 19(2), 203-216.

Tabachnick, B. G. \& Fidell, L. S. (2001). Using Multivariate Statistics (4. Bask1.). MA: Allyn\&Bacon, Inc.

Türkiye İstatistik Kurumu, (2019). 2019 Y1lı Mart ayı işgücü araştırma sonuçları. http://www.tuik.gov.tr/ Adresinden 19.06.2019 tarihinde alınmıștır.

Van der Heijde, C. M. \& Van der Heijden, B. I. (2005). The development and psychometric evaluation of a multi-dimensional measurement instrument of employability and the impact of aging. International Congress Series, 1280, 142-147. doi:10.1016/j.ics.2005.02.061

Vanhercke, D., De Cuyper, N., Peeters, E. \& De Witte, H. (2014). Defining perceived employability: A psychological approach. Personnel Review, 43, 592605. doi:10.1016/j.ics.2005.02.061. 
Ek-1: Altı Faktörlü Modele İlişkin Doğrulayıcı Faktör Analizi Bağlantı Diyagramı Katsayıları

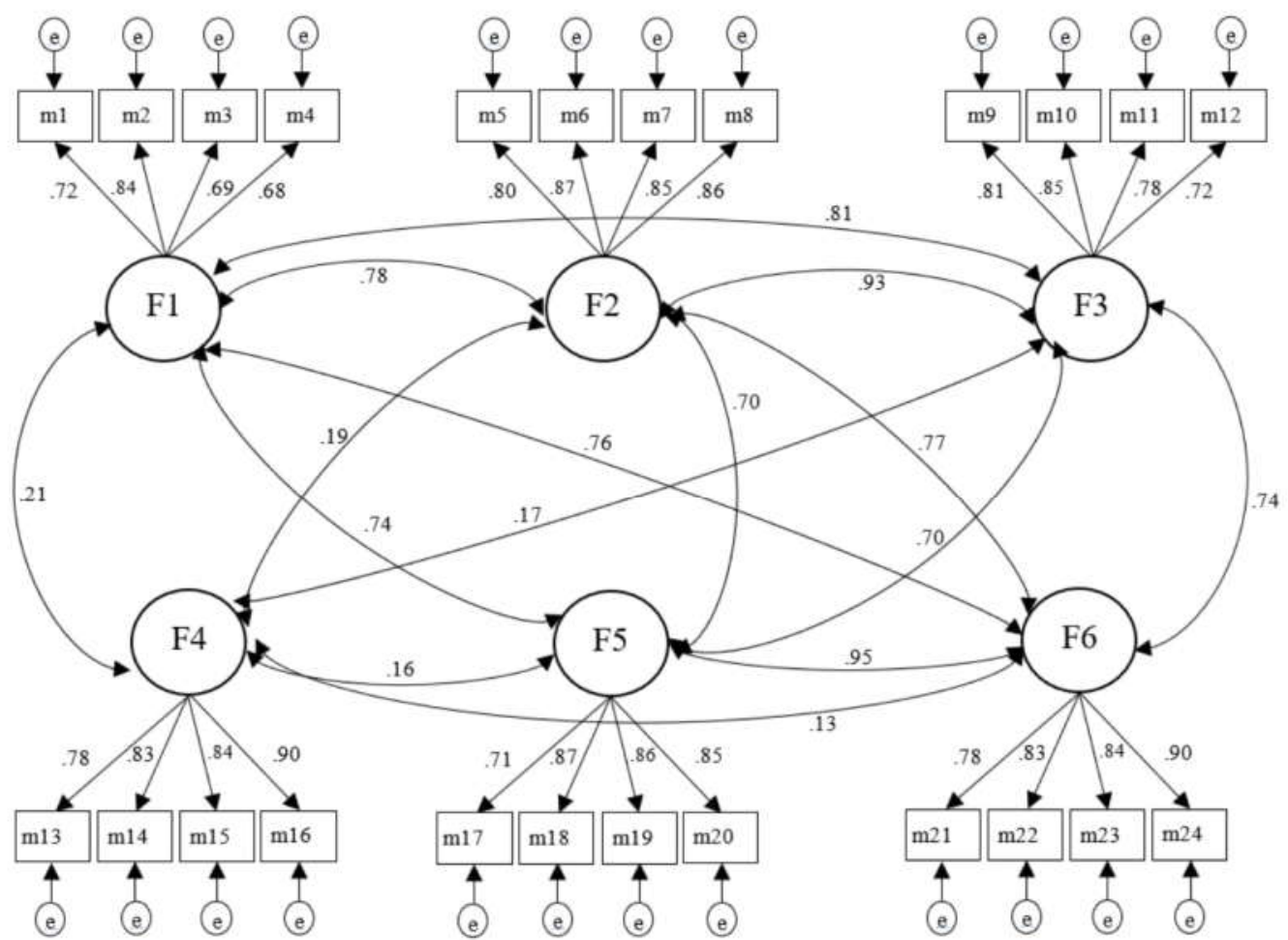

Not: F1: Algılanan gelecekteki iletișim ağ1; F2: Algılanan gelecekteki deneyimler; F3: Algılanan gelecekteki kişisel özellikler; F4: Eğitim kurumunun beklenen itibarı; F5: Algılanan gelecekteki iş gücü piyasası bilgisi; F6: Algılanan gelecekteki beceriler.

Ek-2: İkinci Düzey Altı Faktörlü Modele İlişkin Doğrulayıcı Faktör Analizi Bağlantı Diyagramı Katsayıları

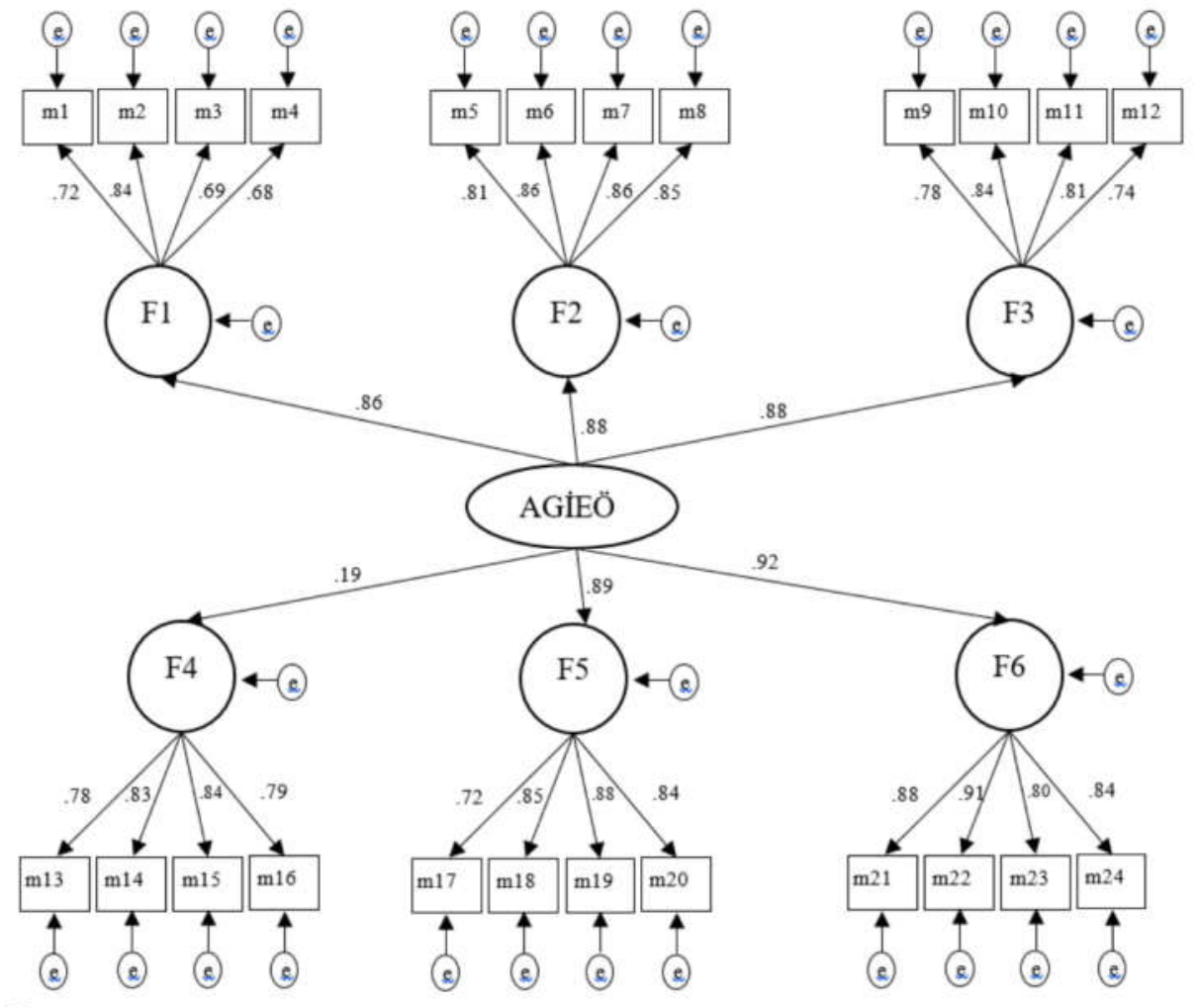

Not: F1: Algılanan gelecekteki iletişim ağ1; F2: Algılanan gelecekteki deneyimler; F3: Algılanan gelecekteki kișisel özellikler; F4: Eğitim kurumunun beklenen itibarı; F5: Algılanan gelecekteki iș gücü piyasası bilgisi; F6: Algılanan gelecekteki beceriler; AGIEÖ: Algılanan Gelecekteki Istihdam Edilebilirlik Ölçeği. 
Ek-3: Tek Faktörlü Modele Ilişskin Doğrulayıcı Faktör Analizi Bağlantı Diyagramı Katsayılanı

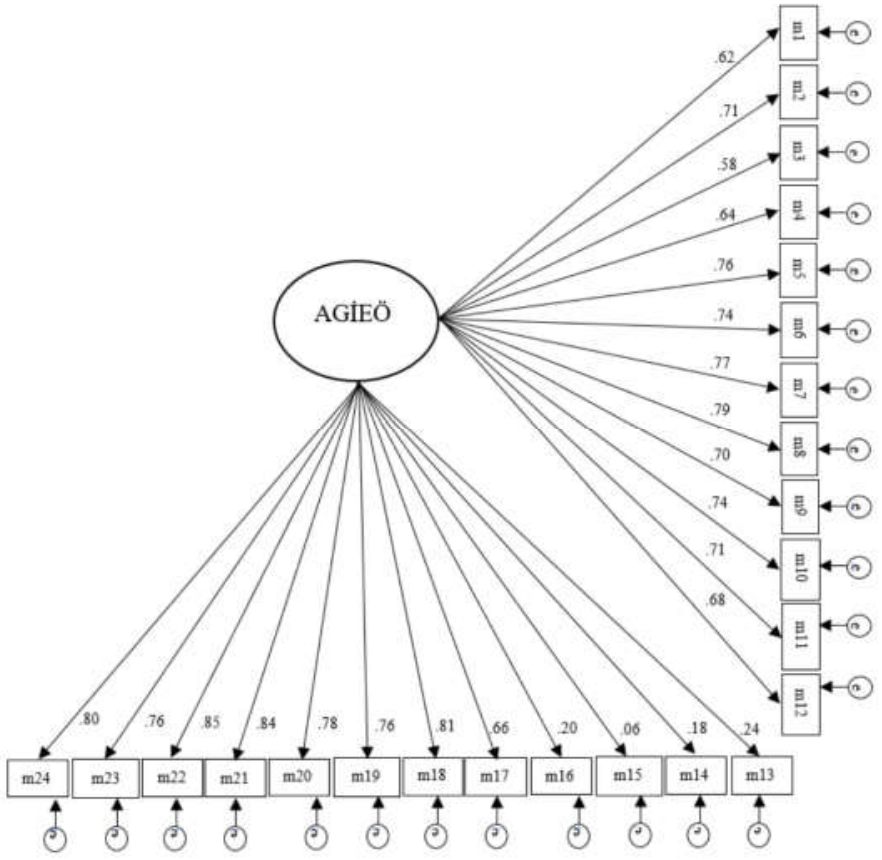

Not. AGİEÖ: Algılanan Gelecekteki Istihdam Edilebilirlik Ölçeği.

Ek-4: Bifaktör Modele İlişkin Doğrulayıcı Faktör Analizi Bağlantı Diyagramı Katsayıları

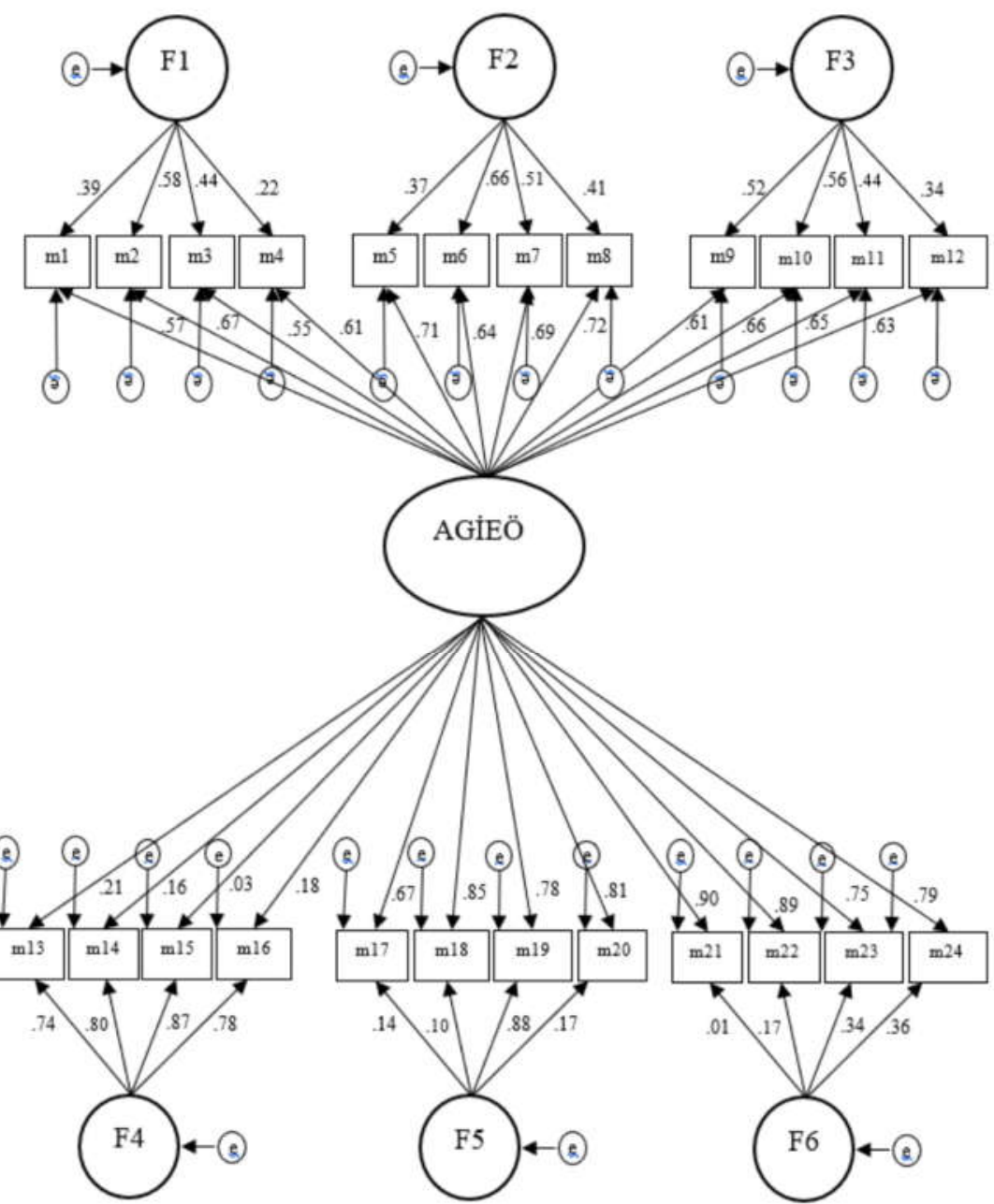

Not: F1: Alglanan gelecekteki iletișim ağ1; F2: Alg1lanan gelecekteki deneyimler; F3: Algılanı gelecektekikişisel özellikler; F4: Eğitim kurumunun beklenen itiban; F5: Alọılanan gelecekteki iş güi piyasası bilgisi; F6: Algilanan gelecekteki beceriler, AGIEÖ: Algılanan Gelecekteki IstihdamEdilebilirl Ölçeği. 
EK-5: Algılanan Gelecekteki İstihdam Edilebilirlik Ölçeği*

\begin{tabular}{|c|c|c|c|c|c|c|c|}
\hline No & $\begin{array}{l}\text { Genç yetişkinlerin üniversite sonrası iş yaşamı ile ilgili pek çok } \\
\text { hedefi ve beklentisi olabilir. Bu konu ile ilgili herkesin birtakım } \\
\text { düşünceleri vardır. Sizden istenen her ifadeyi dikkatlice okuyarak } \\
\text { kendinizi değerlendirmenizdir. Sorular "Kesinlikle katılmıyorum } \\
\text { (1)" ve "Kesinlikle katılıyorum (6)" şeklinde altı derecelidir. } \\
\text { Lütfen kendinize en yakın hissettiğiniz dereceyi işaretleyiniz. } \\
\text { Her bir soru için tek dereceyi işaretleyiniz ve boş madde } \\
\text { bırakmayınız. }\end{array}$ & 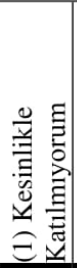 & 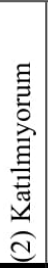 & 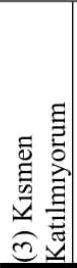 & 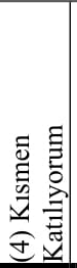 & 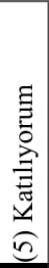 & 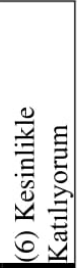 \\
\hline 1 & $\begin{array}{l}\text { İşimde başarılı olmak için kurduğum ilişkilerden } \\
\text { yararlanabileceğim. }\end{array}$ & & & & & & \\
\hline 2 & İşimi iyi yapmamı sağlayacak sosyal ilişkiler ağı kuracağım. & & & & & & \\
\hline 3 & $\begin{array}{l}\text { Olası iş firsatlarını belirlememe yardımcı olabilecek bir iletişim } \\
\text { ağı kuracağım. }\end{array}$ & & & & & & \\
\hline 4 & $\begin{array}{l}\text { Kariyer alanımda iş bulmama yardımcı olabilecek insanlarla nasıl } \\
\text { iletişim kuracağımı bileceğim. }\end{array}$ & & & & & & \\
\hline 5 & $\begin{array}{l}\text { Çalışmalarımdan edindiğim bilgileri kullanarak amacıma uygun } \\
\text { iş tecrübesine sahip olacağım. }\end{array}$ & & & & & & \\
\hline 6 & $\begin{array}{l}\text { Gelecekteki işverenlerim, biriktirmiş olduğum iş deneyiminden } \\
\text { etkilenecekler. }\end{array}$ & & & & & & \\
\hline 7 & $\begin{array}{l}\text { Gelecekteki işverenlerim kazandığım iş deneyimlerinden } \\
\text { memnun olacaklar. }\end{array}$ & & & & & & \\
\hline 8 & $\begin{array}{l}\text { Gelecekteki işverenlerime, istedikleri uygulama becerilerine ve } \\
\text { akademik tecrübeye sahip olduğumu gösterebileceğim. }\end{array}$ & & & & & & \\
\hline 9 & $\begin{array}{l}\text { Tecrübelerim, başa çıkma gücümün olduğunu ve kolayca pes } \\
\text { etmediğimi gösterecek. }\end{array}$ & & & & & & \\
\hline 10 & $\begin{array}{l}\text { Olası iş verenlerim, iyi motive olduğumu başarılarımdan } \\
\text { görebilecekler. }\end{array}$ & & & & & & \\
\hline 11 & $\begin{array}{l}\text { Olası işverenlerim, kendim için net hedeflerim olduğunu } \\
\text { görebilecekler. }\end{array}$ & & & & & & \\
\hline 12 & $\begin{array}{l}\text { Sicilim (kayıtlarım), güçlü bir iş etiğine sahip olduğumu } \\
\text { gösterecektir. }\end{array}$ & & & & & & \\
\hline 13 & $\begin{array}{l}\text { Gelecekteki işverenlerimin işe alımlarda, diğer üniversitelerden } \\
\text { ziyade benim üniversitemin mezunlarını tercih edeceklerinin } \\
\text { avantajına sahip olacağım. }\end{array}$ & & & & & & \\
\hline 14 & $\begin{array}{l}\text { Eğitim aldığım üniversitenin itibarı, iş ararken bana çok önemli } \\
\text { bir kazanç sağlayacak. }\end{array}$ & & & & & & \\
\hline 15 & $\begin{array}{l}\text { Eğitim aldığım üniversitenin çok sayıda olası işverenle güçlü } \\
\text { ortaklıkları olduğu için, bana açık pek çok iș firsatı olacak. }\end{array}$ & & & & & & \\
\hline 16 & $\begin{array}{l}\text { Üniversitemin mezunları yüksek talep gören çalışma pozisyonları } \\
\text { konusunda iyi bir şekilde yetiştirildiği için, aranılan biri } \\
\text { olacağım. }\end{array}$ & & & & & & \\
\hline 17 & Benim için mevcut olan çeşitli iş firsatlarına hakim olacağım. & & & & & & \\
\hline 18 & $\begin{array}{l}\text { Kariyerimde iyi olmak için atmam gereken adımları } \\
\text { öğreneceğim. }\end{array}$ & & & & & & \\
\hline 19 & Seçtiğim alandaki iş firsatlarını keşfetme becerimi geliştireceğim. & & & & & & \\
\hline 20 & $\begin{array}{l}\text { Seçtiğim alandaki mesleki eğilimler konusunda güncel } \\
\text { kalacağım. }\end{array}$ & & & & & & \\
\hline 21 & İstediğim işi elde etmek için gereken bilgileri kazananacağım. & & & & & & \\
\hline 22 & Seçtiğim mesleğe uygun becerilere sahip olacağım. & & & & & & \\
\hline 23 & $\begin{array}{l}\text { Gelecekteki işverenlerim, istedikleri bilgileri ve alana uygun } \\
\text { özel/teknik becerileri öğrenmiş olacağımı görecekler. }\end{array}$ & & & & & & \\
\hline 24 & $\begin{array}{l}\text { Gelecekteki işverenlerimin sıklıkla ihtiyaç duyacakları mantıklı } \\
\text { düșünme ve problem çözme becerilerimi geliștirmiș olacağım. }\end{array}$ & & & & & & \\
\hline
\end{tabular}

* Bilimsel ilkelere bağlı kalmak ve uygun biçimde atıf yapmak koşuluyla yazarlardan izin almadan ölçeği araştırmalarınızda kullanabilirsiniz. 